\title{
AKTIVITAS ANTIBAKTERI EKSTRAK KULIT BUAH PEPAYA CALIFORNIA (Carica papaya L) TERHADAP BAKTERI Escherichia coli
}

\author{
Romauli Anna Teresia Marbun, Novidawati Boru Situmorang \\ Institut Kesehatan Medistra Lubuk Pakam \\ e-mail: romamarbun60@yahoo.com
}

\begin{abstract}
Infectious diseases caused by bacteria, require antibiotics for treatment. Incorrect use of antibiotics causes the occurrence of resistance. From the research, it was found that many medicinal plants can be used to cure infectious diseases. One of them is California Papaya rind (Carica papaya $L$ ). California papaya The purpose of this study was to determine the active substance in the skin of the California Papaya rind as an antibacterial agent and to determine the activity of extract against $E$. coli bacteria. This research method is a laboratory experiment where the sample in this study is $3 \mathrm{~kg}$. Method of extraction is maseration. Phytochemical test results that ethanol extract containing flavonoids, saponins, steroids. Where flavonoids can be potential as antibacterial through 3 mechanisms, namely by inhibiting nucleic acid synthesis, inhibiting cell membrane function and inhibiting energy metabolism. The results of the antibacterial activity test against $E$. coli bacteria were carried out with several concentrations, namely 20\%, 40\%, $60 \%, 80 \%, 100 \%$, tetracylin as positive control, and DMSO as negative control. The test results obtained from the concentration of $20 \%$ of $8.76 \mathrm{~mm}$ the highest inhibitory power at the concentration $100 \%$ of $19.33 \mathrm{~mm}$. The Conclusion is California Papaya Fruit extract has antibacterial activity against E. Coli bacteria.
\end{abstract}

Keywords: California papaya extract; antibacterial; Escherchia coli

\section{PENDAHULUAN}

Banyak gangguan maupun penyakit yang dapat ditimbulkan oleh bakteri dengan menginfeksi bagian tubuh tertentu. Salah satu bakteri yang dapat tumbuh dan berkembang bahkan menyebabkan kerusakan pada tubuh manusia yaitu bakteri Escherichia coli. Escherchia coli merupakan salah satu flora normal pada usus besar manusia yang bersifat gram negatif enterik (Enterobactericeae). Namu bila bakteri ini berada di luar usus maka akan bersifat patogen(Nova, 2017).

Beberapa penelitian menyatakan bahwa $E$. coli sering menimbulkan beberapa penyakit infeksi seperti pada saluran kemih, saluran empedu dan rongga perut. Selain itu penelitian juga menyimpulkan penyebab utama penyakit diare disebabkan oleh bakteri $E$. coli (Desrini, 2015).

Jenis penyakit yang banyak diderita saat ini adalah penyakit karena infeksi terutama di Negara berkembang termasuk indonesia. Infeksi merupakan proses masuk dan berkembangnya mikroorganisme kedalam tubuh yang seharusnya dalam keadaan normal mikroorganisme tersebut tidak terdapat didalam tubuh. Penyakit infeksi terjadi ketika interaksi dengan mikroba berbagai gejala dan tanda klinis. Terapi yang diberikan untuk penyakit infeksi 
yaitu dengan pemberian antibiotik. Pemakaian antibiotika yang tidak tepat dapat menyebabkan terjadinya resisten terhadap pasien menderita infeksi (Zulmiyusrini, 2015).

Saat ini World Health Organization (WHO) merekomendasikan obat tradisional sebagai terapi untuk pemeliharaan kesehatan, pencegahan dan pengobatan penyakit terutama untuk penyakit kronis, degenerative dan kanker (Dwisatyadini, 2017).

Kulit buah pepaya california (Carica papaya L) merupakan salah satu tanaman yang dapat digunakan sebagai tanaman obat. Berdasarkan hasil penelitian terdahulu Citra mengatakan bahwa Ekstrak Etanol Kuli Pepaya (EEKP) muda terbukti dapat menghambat pertumbuhan bakteri Stapylococcus aureus dengan konsentrasi terendah $25 \%$ sebesar 0,55 $\mathrm{mm}$ sedangkan daya hambat pertumbuhan bakteri paling tinggi dengan konsentrasi $100 \%$ sebesar 2,95 mm. Hal ini dikarenakan adanya kandungan senyawa berupa steroid, flavonoid, dan saponin yang terdapat pada ekstrak EEKP. Senyawa flavonoid ini mampu membentuk ikatan kompleks dengan protein pada dinding sel bakteri, sehingga aktivitas sel terganggu dan mengakibatkan kematian pada bakteri. Senyawa antibakteri yang terkandung pada kulit buah pepaya muda seperti saponin juga dapat ditemukan didalam pepaya california (Carica papaya L) (Citra dkk, 2018).

Berdasarkan uraian di atas, dan belum adanya penelitian yang mengujiefek antibakteri terhadap bakteri Escherchia coli, maka peneliti tertarik untuk meneliti apakah ekstrak kulit buah pepaya california juga berkhasiat sebagai antibakteri terhadap bakteri Escherchia coli. Maka pada penelitian ini akan dilakukan "Menguji Aktivitas Antibakteri Ekstrak Kulit Buah Pepaya California
Marbun \& Situmorang, Aktivitas Antibakteri Ekstrak, ... (Carica papaya L) Terhadap Bakteri Escherchia coli".

\section{METODE}

\section{Jenis dan Desain Penelitian}

Penelitian ini dilakukan menggunakan desain true experiment (experiment murni) secara kuantitatif yang dilaksanakan di Laboratorium Mikrobiologi Fakultas Farmasi Institut Kesehatan Medistra Lubuk Pakam dimana aktivitas antibakteri diukur diameternya menggunakan jangka sorong dengan satuan milimeter.

\section{Bahan}

Bahan yang digunakan antara lain ekstrak kulit buah pepaya california diperoleh dari Balige, sumatera Utara dengan sampel Escherichia coli, Pelarut etanol 96\% (Bratachem, Indonesia), $\mathrm{NaCl}$ 0,9\% (B-Braun, Indonesia), Nutrient Agar (MerkAlat $\AA$, Indonesia), Dimethyl Sulfoxide (DMSO) (MerkAlat ${ }^{\circledR}$, Indonesia).

\section{Alat}

Alat yang digunakan antara lain Aluminium foil, autoklaf, batang pengaduk, blender, beaker glass, cawan petri, cawan porselin, deck glass, erlenmeyer, gelas ukur, inkubator, jangka sorong, jarum ose, objek glass, kain kasa, kapas, kertas cakram, kertas label, kertas perkamen, kulkas, laminal air flow, lampu bunsen, lumpang dan stamper, neraca analitik, oven, pinset, pipet mikro, rak tabung, rotary evaporator, spatula, dan tabung reaksi. 


\section{Alur penelitian}

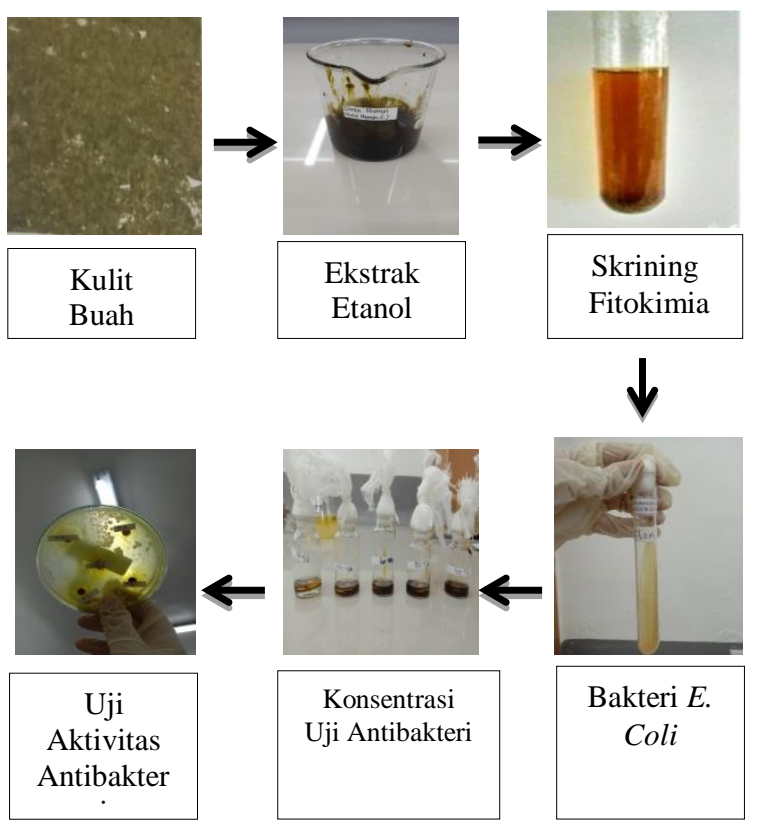

\section{Pembuatan Ekstrak Etanol Kulit Pepaya California}

Pembuatan ekstrak EEKP dilakukan dengan metode maserasi menggunakan pelarut etanol $96 \%$ yang direndam beberapa hari. Sampel basah (kulit segar) pepaya california yang dikumpulkan sebanyak 5 kilogram, kemudian dikeringkan dengan suhu kamar yang terhindar dari paparan sinar matahari secara langsung agar kandungan metabolit sekunder dalam tumbuhan tidak rusak oleh suhu yang tinggi dan didapatkan sampel keringnya 1,2 kilogram kemudian diblender dan dipeeroleh serbuk 1,1 kilogram. Hasil filtrat dipekatkan dengan rotary evaporator.

\section{Pembuatan Media Bakteri}

Nutrient Agar (NA) sebanyak 7 gram masukkan dalam erlenmeyer kemudian larutkan dalam aquadest $250 \mathrm{ml}$. Setalh mendidih larutan disterilkan pada suhu $121^{\circ} \mathrm{C}$ selama 15 menit autoklaf.

\section{Pembuatan \\ Antibakteri}

Media

Uji

Pengujian antibakteri dilakukan menggunakan metode difusi cakram dalam 5 tabung reaksi yang masing-
Marbun \& Situmorang, Aktivitas Antibakteri Ekstrak, ... masing telah berisi EEKP dengan konsentrasi $100 \%, 80 \%, 60 \%$, 40\% dan $20 \%$. Tiap cawan petri diberi label kemudian label bertuliskan ekstrak konsentrasi $100 \% \quad 1$ garm, ekstrak konsentrasi $80 \% \quad 0,8$ gram, ekstrak konsentrasi $60 \% \quad 0,6$ gram, ekstrak konsentrasi $40 \% \quad 0,4$ gram, ekstrak konsentrasi $20 \%$ 0,2 gram.

\section{Uji Aktivitas Antibakteri}

Dalam setiap cawan petri steril dituangkan media broth sebanyak $15 \mathrm{ml}$. Bakteri Escherichia coli sebanyak 1-2 ose disuspensikan menggunakan $\mathrm{Nacl}$ 0,9\% sesuai dengan standar Mc. Farland (1 x $108 \mathrm{CFU} / \mathrm{ml}$ ) disebar diatas media masing-masing sebanyak $200 \mu \mathrm{L}$.

Kemudian cawan petri dihomogenkan serta kertas cakram dipindahkan secara aseptic menggunakan pinset steril ke konsentrasi 20\%, 40\%, $60 \%$, 80\%, dan $100 \%$. EEKP dimasukkan kedalam media NA yang diddalamnya telah berisi bakteri Escherichia coli, setelah itu diinkubasi pada inkubator selama $1 \times 24$ jam dengan suhu $37^{\circ} \mathrm{C}$ dan diamati zona hambatnya.

\section{HASIL DAN PEMBAHASAN}

Dalam penelitian Tetrasiklin digunakan sebagai kontrol positif ujia antibakteri. Dimana kontrol positif membandingkan daya hambat dari EEKP california (Carica papaya L) dengan obat kimia yang terbukti dan sering digunakan sebagai antibakteri. Uji kemampuan daya hambat dari ekstrak etanol kulit buah pepaya california terhadap pertumbuhan bakteri Escherichia coli dilakukan menggunakan 5 konsentrasi yakni mulai dari konsentrasi 20\%, 40\%, 60\%, 80\%, $100 \%$. Efektivitas suatu zat sangat dipengaruhi oleh konsentrasi yang diberikan maka dengan demikian semakin besar konsetrasi zat yang diberikan semakin besar komponen bioaktif suatu zat yang terkandung didalmnya. Hasil uji 
aktivitas antibakteri EEKP dapat dilihat pada tabel 1.

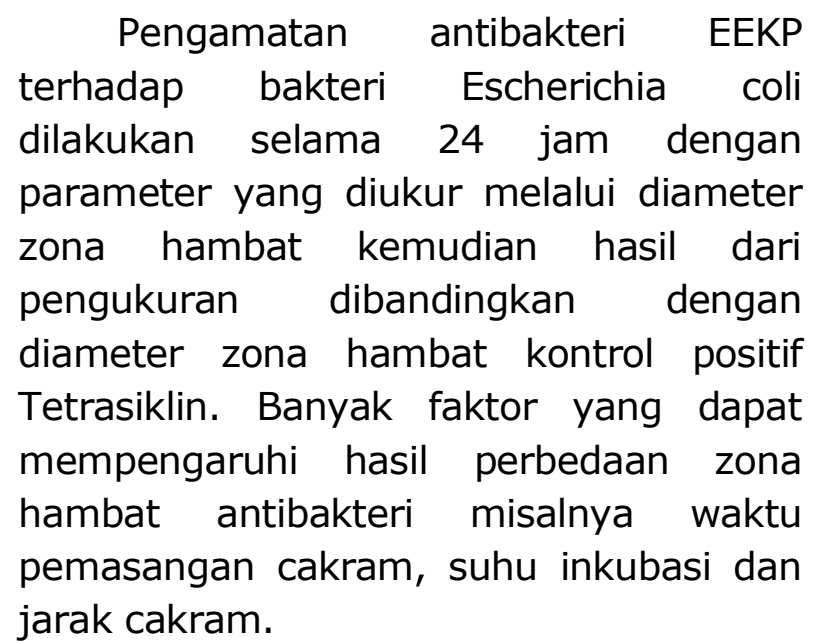

Tabel 1. Hasil Uji Aktivitas Antibakteri EEKP

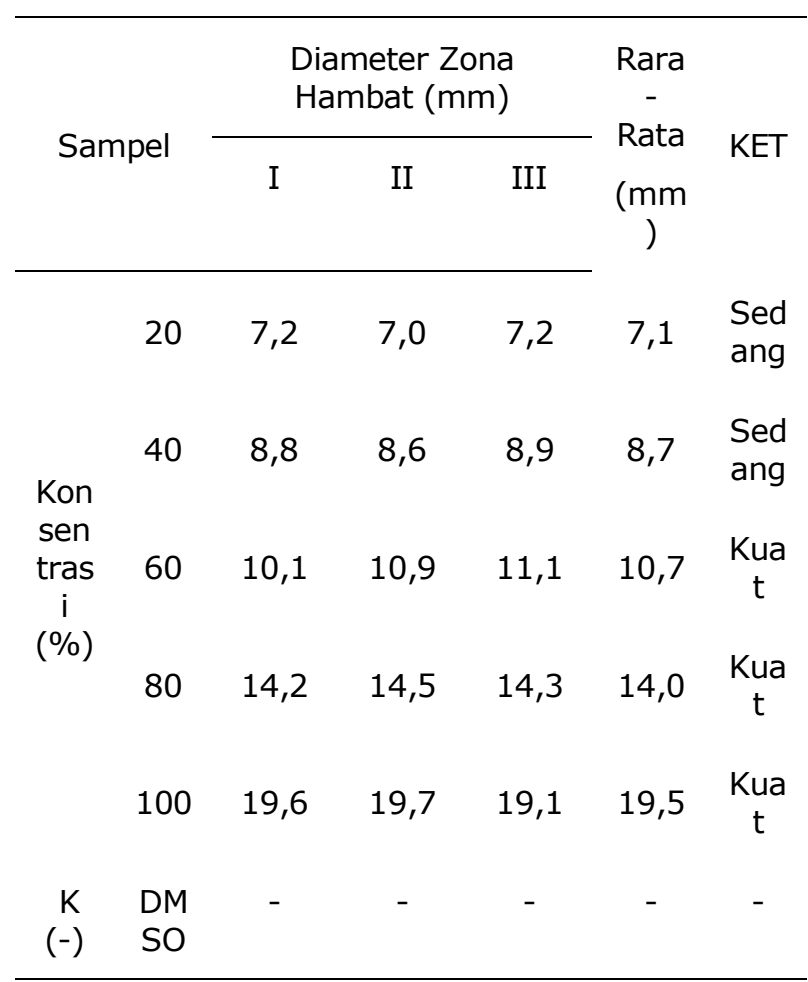

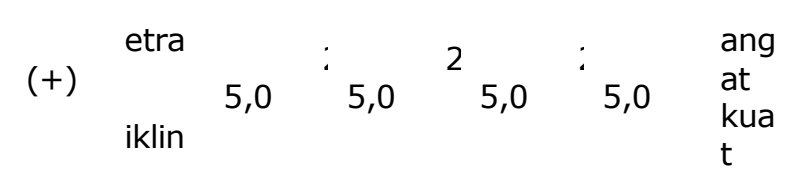

Keterangan :

Diameter Zona Hambat (DZH)

DZH besar 20 milimeter :

Sangat Kuat

DZH 10 sampai 20 milimeter : Kuat

DZH 5 sampai 10 milimeter :
Marbun \& Situmorang, Aktivitas Antibakteri Ekstrak, ... DZH 0 sampai 5 milimeter: Lemah

Konsentrasi EEKP terhadap pertumbuhan bakteri Escherichia coli dengan konsentrasi $100 \%$ diameter zona hambat terbesar yaitu 19,5 milimeter dengan katagori kuat, diikuti konsentrasi $80 \%$ sebesar 14,0 milimeter yang termasuk katagori kuat, diikuti konsentrasi $60 \%$ sebesar 10,7 milimeter yang termasuk katagori kuat, konsentrasi $40 \%$ sebesar 8,7 milimeter yang termasuk kategori sedang dan konsentrasi $20 \%$ sebesar 7,1 milimeter yang termasuk kategori sedang.

Zona hambat pertumbuhan bakteri ini dapat dilihat dengan adanya zona bening disekitar cakram hal ini dikarenakan hasil skrining sampel uji positif mengandung flavonoid yang memiliki efek antibakteri dengan mekanisme merusak dinding sel bakteri dengan pembentukan senyawa kompleks protein ekstraseluler, menghambat sinteis asam nukleat. Selain itu juga terdapat saponin dengan efektivitas antibakteri melalui proses peningkatan permeabilitas membran sel sehingga disimpulkan bahwa EEKP dapat menghambat pertumbuhan bakteri Escherichia coli.

\section{SIMPULAN DAN SARAN}

\section{Kesimpulan}

Ekstrak kulit buah pepaya california memiliki daya antibakteri terhadap bakteri Escherichia coli yang dibuktikan adanya diameter daya hambat maka dengan demikian ekstrak kulit buah pepaya california efektif terhadap bakteri Escherichia coli.

\section{Saran}

Penelitian selanjutnya agar melakukan ekstrak kulit buah pepaya california terhadap bakteri Escherichia coli pada hewan percobaaan. 


\section{DAFTAR PUSTAKA}

Citra,T. (2018). Aktivitas Antibakteri Ekstrak Etanol Kulit Buah Pepaya Muda (Carica papaya L) Terhadap Escherichia coli dan Staphylococcus aureus secara In Vitro. Jurnal Medikes. Vol.5. Ed.2.

Desrini, S. (2015). Resistensi antibiotik, akankah dapat dikendalikan. JKKI. Vol.6 (4) : 1 - 3 .

Dwisatyadini, M. (2017). Pemanfaatan Tanaman Obat untuk Pencegahan dan Pengobatan Penyakit Degeneratif. In: Optimalisasi Peran Sains dan Teknologi untuk Mewujudkan Smart City. Tangerang Selatan: Universitas Terbuka, ISBN 978-602-392-158-4 (e).

Fajeriyati, Andika. (2017). Uji Aktivitas Antibakteri Ekstrak Etanol Rimpang Kencur (Kaempferia galanga L) Pada Bakteri Bacillus subtilis dan Escherichia coli. Journal. Vol.1 No. 1

Nova, Suryati. (2017). Uji Efektivitas Antibakteri Ekstrak Aloe vera Terhadap Pertumbuhan Escherichia coli secara In Vitro. Jurnal Kesehatan Andalas : 6 (3).

Zulmiyusrini, P. (2015). Infeksi. (Online).(http://www.kerjanya.net /faq/12111infeksi.html/). 